\title{
The Promotion of the 21 st Century Learning Skills Through the Development of Games Using Scratch
}

\author{
Ana Maria Ferreira Lopes Oliveira Pinto \\ Games, Interaction and Learning Technologies (GILT), \\ College of Engineering, \\ Porto's Polytechnic Institute \\ analopes.pinto@gmail.com
}

\author{
Paula Maria de Sá Oliveira Escudeiro \\ Games, Interaction and Learning Technologies (GILT), \\ College of Engineering, \\ Porto's Polytechnic Institute \\ pmo@isep.ipp.pt
}

\begin{abstract}
O$ estudo apresentado neste artigo aborda aspetos relacionados com o desenvolvimento de jogos focados numa estratégia de ensino/aprendizagem suportada por uma metodologia de investigação-ação. A estratégia estabelecida visa testar o impacto da participação do aluno num projeto colaborativo. $O$ principal objetivo do projeto consistiu na criação de condições para fomentar a motivação dos alunos a utilizar e aprender línguas estrangeiras, bem como a desenvolver a sua competência comunicativa intercultural. A equipa foi formada por 14 professores de 11 países diferentes $e$ 167 estudantes num contexto educacional internacional. No que diz respeito à participação portuguesa, introduzimos a Área de Estudo, designadamente o Area de Descoberta, numa turma dos alunos do $7^{\circ}$ ano (23 alunos). Todo o trabalho foi baseado em três premissas: utilização do Scratch online, a web 2.0 e a plataforma eTwinning. Estudantes de diferentes países trabalharam juntos para desenvolver os seus próprios jogos usando a programação Scratch. Durante o projeto, os parceiros colaboraram usando as ferramentas da web 2.0 e no final, eles compartilharam seus jogos e receberam feedback. Este trabalho identificou os beneficios e desafios da educação global $e$ interação intercultural entre os alunos. Catorze escolas de 11 países europeusparticiparam neste projeto eTwinning. Seis escolas ganharam o título europeu de qualidade eTwinning. A metodologia aplicada neste ambiente de aprendizagem motivou os alunos e melhorou o seu processo de aprendizagem. Também contribuiu para um maior nível de concentração e promoveu a aprendizagem colaborativa. Além disso, facilitou a criatividade, o diálogo e a relação global entre os alunos. Os resultados demonstram que os professores percebem que o eTwinning contribui para a melhoria e o desenvolvimento da educação global através da interação intercultural. O modelo pedagógico baseado na construção colaborativa do conhecimento foi facilmente compreendido pelos professores, já que todos conseguiram concluir o projeto.
\end{abstract}

Palavras chaves - aprendizagem, aprendizagem colaborativa, ensino, Scratch, educação, desenvolvimento de jogos, etwinning.

Abstract - The work described in this paper addresses the development of a game focused on a teaching strategy based on an action-research study. The strategy established aims to test the impact of the student's participation in a collaborative project. The project aimed to motivate students to use and learn foreign languages and also to develop their intercultural communicative competence. The team consisted of 14 teachers from 11 different countries and 167 students in an international educational context. Regarding the Portuguese participation, we have introduced the Area of Study namely Discovery in a class from the 7th grade students (23 students). All the work was based in three premises: use Scratch online, web 2.0 and ETwinning platform. Students from different countries have worked together to develop their own games using programming Scratch. During the project, partners collaborated using web 2.0 tools and at the end, they have share their games and get feedback. This work identified the benefits and challenges of global education and intercultural interaction among students. Fourteen schools from 11 European countries have participated in this eTwinning project. Six schools had won the European quality eTwinning label. The methodology applied in this learning environment motivated the students and improved their learning process. It also contributed to a higher level of concentration and promoted collaborative learning. Additionally, it facilitates creativity, dialogue and the overall relationship among students. The results demonstrate that teachers perceive eTwinning as contributing towards the enhancement and development of global education through intercultural interaction. The pedagogic model based on the collaborative construction of knowledge was easily understood by the teachers.

Keywords - learning, collaborative learning, Scratch, education, games developed, etwinning

\section{INTRODUCTION}

Programming and computational thinking skills are becoming ever more important in our society and working life. Learning to code develops various skills such as problemsolving, logical reasoning and creativity, and it can help student motivation in mathematics theory as it encourages them to apply their knowledge. Schools are key players in introducing programming to students in an engaging way, and help to defuse negative stereotypes concerning computer science.

Today students are facing a global society which is interconnected. These needs competencies in digital and cultural integration skills to become successful global

This work will be focusing on the benefits and challenges of global education and intercultural interaction amongst students participating in eTwinning projects between various European countries.

In this project there are fourteen teachers who share ideas about educational systems, methologies and pedagogies used,

Globalization is a phenomenon taking place all across the globe as people of different nations communicate and interact more efficiently through technology. International issues and diverse cultures are increasingly being introduced in the classroom through global education which encompasses related terms such as "world education", "intercultural awareness", "global awareness "and "cross-cultural interaction" using "world" or "international" to replace global., recommendations will also be suggested.

While the graphic "Fig. 1" represents each element distinctly for descriptive purposes, $\mathrm{P} 21$ views all the components as fully interconnected in the process of 21 st century teaching and learning. 


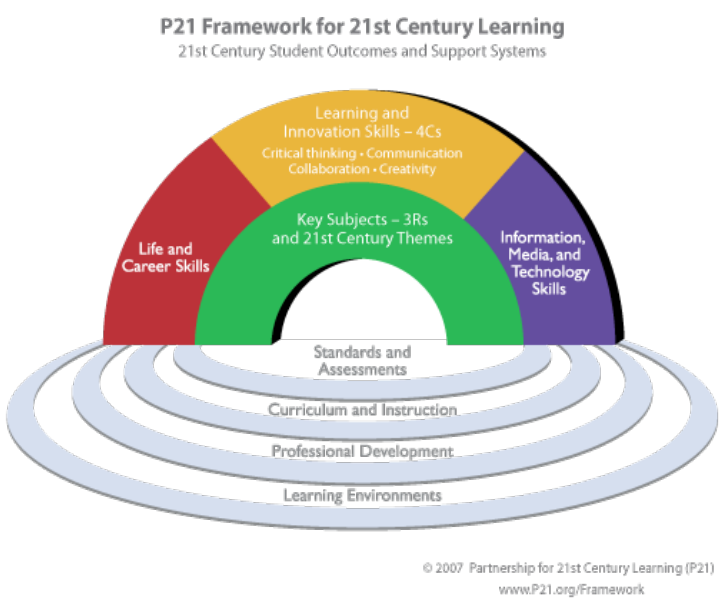

Figure 1. P21 Framework for 21 st century Learning

The elements described below are the critical systems necessary to ensure 21 st century readiness for every student. 21 st century standards, assessments, curriculum, instruction, professional development and learning environments must be aligned to produce 21 st century outcomes for today's students.

This work aims to present the didactic-pedagogic potential of project ETwinning "Scratch Create Games", learn to think creatively, plan systematically, analyse.

\section{ETWINNING}

The traditional concept of literacy is changing. In the $21 \mathrm{st}$ century people need more than Reading, Writing and Using arithmetic, to be able to compete in a global world

Launched in 2005 as the main action of the European Commission's eLearning Programme, eTwinning has been firmly integrated in Erasmus+, the European programme for Education, Training, Youth and Sport, since 2014. Its Central

Support Service is operated by European SchoolNet, an international partnership of 30 European Ministries of Education developing learning for schools, teachers and pupils all over Europe. eTwinning is further supported at national level by 37 National Support Services, it offers a platform for staff (teachers, head teachers, librarians, etc.), working in a school in one of the European countries involved, to communicate, collaborate, develop projects, share and, in short, feel and be part of the most exciting learning community in Europe, and promotes school collaboration in Europe through the use of Information and Communication Technologies (ICT) by providing support, tools and services for schools. ETwinning also offers opportunities for free and continuing online Professional Development for educators.

\section{SCRATCH AND THE DEVELOPMENT OF 21ST CENTURY LEARNING SKILLS}

Scratch is part of a new generation of technologies designed to help to prepare students for a Creative Society. To succeed in today's Creative Society, and in support of the mentioned 21st century learning skills, students must learn to think creatively, plan systematically, analyze critically, work collaboratively, communicate clearly, design iteratively, and learn continuously.

The report "Learning for the 21st Century" identifies nine types of learning skills which are divided into three key areas. The hand-out provided highlights the ways in which Scratch supports the development of the so called 21 st century learning skills.

Scratch is built on the constructionist ideas of Lego (Kafai and Resnick 1996; Papert 1080) and Etoys (Kay 2010; Steinmetz
2002). The Scratch website provides a social context for Scratch users and allows them to share their Scratch projects and learn from the projects of others (Resnick et al. 2009).

On the first context is about the Information and Communication Skills; by working on Scratch projects, students learn to select, create, and manage multiple forms of media, including texts, images, animation, and audio recordings via the integration of a variety of media in order to express themselves creatively and persuasively.

On the second context is about the Thinking and Problemsolving Skills; with Scratch, and in order for students to build projects, they need to coordinate the timing and interactions between multiple "sprites" (software's name for objects) and this provides them with direct experience with sensing, feedback and other fundamental system concepts. Scratch supports problem finding and solving in a meaningful design context, as well as encouraging creative thinking - an increasingly important skill in today's fast changing world.

The third context is about the Interpersonal and SelfDirectional Skills; the visual objects and modular code of Scratch supports collaboration and enables students to work together on projects and exchange objects and code. As the Scratch programmed is shareable, it leads to the discussion of important issues with other members.

Scratch is a particularly promising environment for developing scientific models. Scratch uses an innovative interface which allows students (and teachers) to create or to modify computer models with very little training on how to programmed. The interface "Fig. 2" allows users to drag and connect "blocks" (script elements) together into scripts that control the actions of "sprites" on the screen. Blocks of different types are identified by their colour and shape to help young programmers to learn what combinations of scripts are possible.

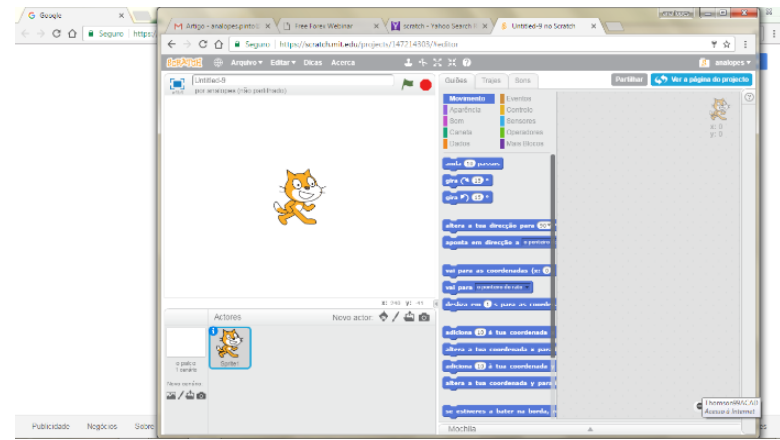

Figure 2. Scratch on line Sofware

Scratch programmed are object oriented - making it easier for objects to behave independently-like objects in the real world. Objects (called "sprites") have basic properties such as location, size and dress, as well as other variables that the user can define. Controland sensingblocksmake iteasy for the programmed toreact to inputs like the mouse or keyboard to create interactive games.

\section{PROJECT ETWINNING - "CREATING GAMES USING SCRATCH"}

The Project Name is "Creating Games Using Scratch" is Initial Activity in 05.10.2015, the Project Subjects was Cross Curricular, Design and Technology, Informatics / ICT, Media Education, Technology, the Project Languages was EN - ES - TR, the Pupil's Age was 11-15.

Project Tools was Audio conference, Chat, e-mail, Forum, MP3, Other software (Powerpoint, video, pictures and drawings), Project diary, TwinSpace, Video conference, Virtual learning 
environment (communities, virtual classes, ...), Web publishing

The Project Aim was that Students will collaborate to design a game using programming cards. Students will share their games and get feedback.

\section{A. Project Summary}

"We aimed to do a collaborative project that brings children from various countries together to create their own games using Scratch. We wanted to promote the use of ICT in teaching. The subject of the project is part of our curriculum. During the project, partners collobarated using web 2.0 tools. Students were divided into small groups. Each group discussed their ideas and they decided their game characters, roles and what would happen when players win or lost. They prepared storyboards, including sketch of scenes and descriptions. They made a flipbook of storyboards and shared in web pages. Then students brought ideas, resources and storyboards together and created games in Scratch and shared them in scratch.mit.edu. Students presented their works on smart boards, school TV and etwinning corner in school. We organized a competition for choosing the best works. Partners voted for the best work and we chose the winner. All works were shared in EBA website, twinspace and project pages."

\section{B. Project Partners and members}

This project has two founders, Alvaro Gosp Pastor, IES LAS ESPEÑETAS, Orihuela from Spain, and Işıl Gülmez, Şirinevler İmam Hatip Ortaokulu, Bursa from Turkey.

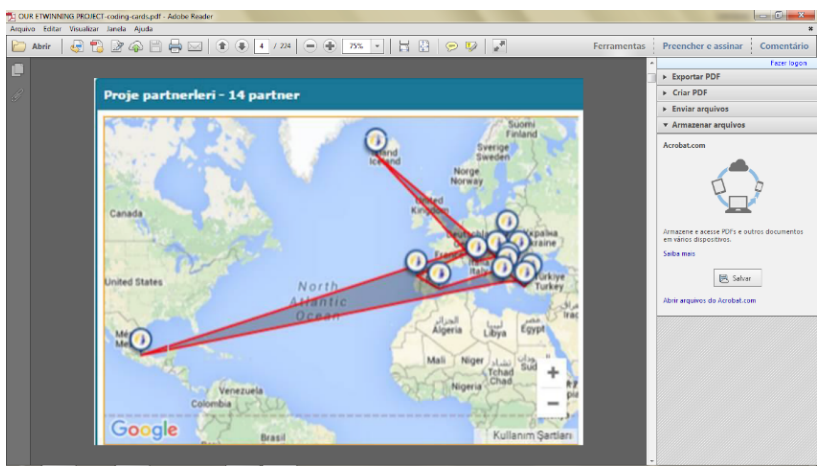

Figure 3. Project Patterns and members of the plan

In this project hthere are fourteen teachers "Fig. 3", Aleksandar Stojković, Osnovna škola "Sreten Mladenović Mika", Ниш, Niš from Serbia, Alvaro Gosp Pastor (Founder), IES LAS ESPEÑETAS, Orihuela, from Spain, Ana Lopes, Colégio Internato dos Carvalhos, Vila Nova de Gaia from Portugal, Anna Lesiak, Zespół Szkół Ogólnokształcących Nr 17 Specjalnych, Kielce from Poland, Dalibor Todorović, Osnovna škola "Sreten Mladenović Mika", Ниш / Niš, from Serbia, Diana Petrova, Средно общообразователно училище"Христо Смирненски", Hisarya, from Bulgaria, George Kefallonitis, 1o Gimnasio Kerkiras, CORFU, from Greece, $\quad \mathrm{H}$ a s a $n$ Ersoy, Eşref Ergin Ortaokulu, Bursa, from Turkey, $\quad$ I $\quad$ ş 11 Gülmez (Founder), Şirinevler İmam Hatip Ortaokulu, Bursa from Turkey, Nataša Majstrović, OŠ "Zmaj Jova Jovanović", Рума, Ruma, from Serbia, Postolache Dumitrita, Colegiul Tehnic „Mihai Viteazu” Vulcan, Vulcan, from Romania,

Sanela Jukić, Eugena Kumičića, Slatina, from Croatia, silvia faggioli, IISS "Aldini-Valeriani-Sirani”, Bologna (BO), from Italy, Ásta Ólafsdóttir, Réttarholtsskóli, Reykjavík, from Iceland.

\section{Work Process}

05.10.2015 - 16.10.2015 Students will introduce themselves to other partners. Students will be divided into small game design groups. Students will use Twinspace, Edmodo and scratch.mit. eduin order to share their ideas. Groups will collobarate using Edmodo, twinspace, e-mails.

19.10.2015 - 06.11.2015

Groups will discuss the game that they will create. Firstly all groups will present the game into its basic parts or key ideas and place them in a logical order to make the model of the game.

All small groups will make a storyboard drawing a rectangle for each scene, and create a sketch of the scenes and a few words to describe what's going on there. They will share their storyboards on Edmodo and will get feedback from other partners.

\subsection{1 .2015 - 27.11.2015}

Students will decide how many characters there will be and the role of the characters. They will also decide what will happen when players win and lose.They will bring their own resources, storyboards and codes together. They will start coding by using Scratch program, add characters and code them. They will create coding cards which show the codes they have used for programming the game and then they will share these codes.

\subsubsection{5-18.12.2015}

When they finished they will upload their project to scratch. mit.edu. The links of the works will be shared on Twinspace and there will be a competition to choose the best works.

\section{Expected Results}

Outputs of these projects will be storyboards and games created by students, game programming cards. The final projects will be shared scratch.mit.edu web site and the project links will be shared on twinspace.

\section{http://twinspace.etwinning.net/9236/home}

\section{RESEARCH DESIGN}

The research design phase is intended to describe a range of activities that will allow the researcher to materialize effectively his/her project. Besides the obvious aim by answering the research questions, the research design phase is implemented in order to control potential sources of bias that can influence the results of the study (Fortin, M., 1999). Thus, this investigation was held under perview of the interpretive paradigm/qualitative, since its ambition is "to understand educational phenomena by seeking personal meanings and interactions between people and contexts" (Coutinho, 2006, p. 3). In addition to the interpretive perspective, this research intends to move towards the improvement of teaching practices in line with the view that "research in education is essential to the development and continuous improvement of educational practice" (Borg \& Gall, 1989, p. 4).

The aim of this investigation was to:

- Provide students with a contact language: Object Oriented Programming

- Enable the operation and development of projects involving programming with Scratch

- Encourage problem solving using Scratch.

This research was developed with the involvement of one class of students in the 7th grade at Colégio Internato dos Carvalhos, Vila Nova de Gaia, Porto. This class has 22 students, 6 girls and 16 boys. All the students were in the 7 th grade for the first time, and there was one special-needs student. The average age of the students was 12 years.

In this plan of action, there are 3 stages:

-1 st stage-Students introduce themselves to other partners. Students were divided into small game design groups. Students 
will use Twinspace, Edmodo and scratch.mit.edu to share their ideas. Groups will collaborate by using Edmodo, twinspace, e-mails.

-2 nd stage - Groups discuss the game they are going to create. Firstly all groups will introduce the game, by decomposing into basic parts or key ideas and place them in a logical order to make the model of the game. All small groups will make a storyboard by drawing a rectangle for each scene, and create a sketch of the scenes and a few words to describe what's going on there. They will share their storyboards on Edmodo and will get feedback from other partners. Students decide how many characters there will be, role of the characters. They will also decide what will happen when players win and lose. They will put their own resources, storyboards and codes together. They will start coding using Scratch program, add characters and code them. They will create coding cards which shows the codes they used for programming the game then they will share it.

$-3^{\text {rd }}$ stage - Once they have finished, they will upload their project to scratch.mit.edu. The links of the works will be shared on Twinspace and there will be a competition for choosing the best works.

\section{ACTION PLAN}

\section{A. The 3rd stage of the plan}

At beginning we have to do the groups: we have decided by three groups of five students and two groups with four students.

The plan of action was in the $1^{\text {st }}$ stage to evaluate several methodologies for the introduction of ETwinning project in the classroom available at:

http://twinspace.etwinning.net/9236/home.

Furthermore, six lessons of 90 minutes "Table I", for project beginners, were planned and these all entailed practical activities for each individual student to perform in class.

TABLE I . Activities plan 1st phase

\begin{tabular}{|c|c|}
\hline Lesson & Activities \\
\hline 1,2 & $\begin{array}{l}\text { Introduction of the Etwinning project } \\
\text { Create the Apresentation }\end{array}$ \\
\hline 3,4 & $\begin{array}{l}\text { Create logotipo } \\
\text { http://cooltext.com// } \\
\text { http://onlinelogomaker.com } \\
\text { https:///www.graphicsprings.com/start- } \\
\text { your-logo }\end{array}$ \\
\hline 5,6 & Use twinspace, Edmodo and emails \\
\hline
\end{tabular}

In the 1st stage, which was the adaptation to Etwinning plataform, twinspace, Edmodo, every student concluded the activities proposed to them, their create de presentation and we were also able to see that the students were very motivate in the classroom.

In this 2 nd stage the students had lessons of 90 minutes "Table II", decided how many characters there will be and the role of the characters. They decided what would happen when players win and lose. They will bring their own resources, storyboards and codes together. They start coding using Scratch program, add characters and code them. They will create coding cards which shows the codes they used for programming the game then they will share it.

At the end of this stage, all five groups have finish the storyboard of the game. It was notorious that they were really excited about creating the ideas of the game, shared and discuss to decide the storyboard of their game. At the end of the stage they really enjoyed showing to the other students the game they had created all by themselves. Finally students had the the chance to show and shared theirs ideas of the storyboard with their parents.

TABLE II .Activities plan 2st phase

\begin{tabular}{|l|l|}
\hline \multicolumn{1}{|c|}{ Lesson } & \multicolumn{1}{c|}{ Activities } \\
\hline 1,2 & Create the storyboard \\
\hline 3,4, & Cenary, ators, role \\
\hline 5,6 & Create codings \\
\hline
\end{tabular}

For the stage, four lessons of 90 minutes "Table III" were planned and these meant that the students had to share their work with others on the Internet. Every student logged on a Scratch website (scratch.mit.edu), created an account and shared their game with other students that were online.

TABLE III .Activities plan 3st phase

\begin{tabular}{|l|l|}
\hline \multicolumn{1}{|c|}{ Lesson } & \multicolumn{1}{c|}{ Activities } \\
\hline 1 & $\begin{array}{l}\text { Upload they game to the account } \\
\text { of the project }\end{array}$ \\
\hline 2,3 & Shared their game \\
\hline 4 & Chosed (voting) the best game \\
\hline
\end{tabular}

During these stages there were some students that finished the activity very quickly and therefore had time to create other examples and further develop their creativity. Every student enjoyed to do the works. They even learned that they didn't need the help of the teacher when they were stuck. Sometimes students their age have much better insight into solving problems in a creative way, and are able to come up with more unique story ideas than the teachers themselves.

\section{B. Use of technology}

We used Skype for our meetings; twinspace, Edmodo and Facebook group for communication and collaboration between partners. Partners created logo suggestions with several online logo design tools. We used powerleague to online voting to choose the project logo. We chose the logo which was more voted. Forms in Google were used to get partner's suggestions during the project. We also used forms in Google at the end to get opinions about the final project. Partners collaborated using twinspace, Edmodo, Facebook, Skype, Google docs and e-mails. We used Doodle tool to plan skype meeting date online. Students introduced themselves by adding slides to project the slideshow by using Google docs. We used www.slideshare.net/ and made a flipbook of presentations using http://publizr.com/ web page. Students joined our Edmodo project group in which they could share their works, make comments on partners' works. Students in groups up to four prepared storyboards drawing scenes of games and descriptions on a piece of paper and afterwards they scanned them to computer. We put them together by using Issuu tool (https://issuu.com). Then we converted storyboards to flipbook with Publizr and shared in on the project pages. Our students used smart boards and digital school TV to present their works to others. They also prepared an etwinning corner and published their works. We used EBA platform to share our works. Students created their own digital games online. Students shared their games in scratch.mit.edu web page, twinspace and all project pages. They commented others' and tried to do their best. We organized a competition to choose the best game. Partners voted online by using tricider (http://tricider.com) and we chose winners. We participated in the Codeweek activities 
(http://events.codeweek.eu/view/4174/coding-is-easy) with our works during the project and got certificates. We created padlet (http://tr.padlet.com/redeemthepast/codeweek) that we shared in our codeweek activities. Students used code.org web page activities during the codeweek.

\section{Collaboration between partner schools}

As project founders, we prepared a project schedule which shows what works need to be performed and when each activities should be done. Partners had to follow with project schedule. We created a project group in Edmodo. Teachers had to add students in Edmodo group and Twinspace. They had to follow student's work and post it . Partners collaborated with Skype, Edmodo, twinspace, Facebook, Google docs and e-mails to share their ideas. We organized Skype meetings to introduce ourselves. We created collaborative slideshow by using Google docs and students could add slides about themselves and their schools. We made a flipbook of this activity and shared it. Students were divided into small game design groups. They discussed about the game that they would create. All groups broke down their games into basic parts and placed them in a logical order. They collaborated to make a storyboard with a sketch of the scenes and a few words to describe what's going on there. They shared their storyboards on twinspace and Edmodo group in which all partners could share their works, see others works and comment them. There, students could also ask questions and get answers from other partners. Collaboratively, students decided the game characters, their roles and what would happen when players win or lose. They created coding cards which show the codes of the game then shared them. We used Google docs to create collaborative slideshow in which students could add their storyboards and coding cards. We made a flipbook of this work. Students brought all their resources together and started creating games using Scratch. When they have finished, they uploaded their games to scratch.mit.edu. The links of the works were shared in Twinspace and all project pages. Students collaborated to learn from each other and they also competed to do the best work on their subject. We organized a competition to choose the best works. All partners voted for the best work and we used online voting system and chose the best work.

\section{RESULT}

In this topic we divide in two sentences, the firsts parts we show the results of the project, in the seconds parts we have the Results, impact and documentation.

\section{A. Results of the project}

Every school have created a similar presentation using the same template. "Fig. 4"in the 1st stage.

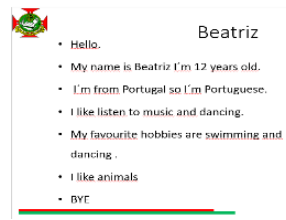

Figure 4. Presentation Template

The Presentations of each School in the Project were published at: http://publizr.com/school/our-etwinning-project. Also, the Coding Cards Flipbook were published at http:// publizr.com/school/our-etwinning-project-coding-cardsson. The Scratch Game Project was published at: https://scratch. mit.edu/users/creatinggames2015/projects/. Finally, the Best Game according to the Vote Contest was the Portuguese game, available at: http://tricider.com/brainstorming/3KqnmZ6PsF3

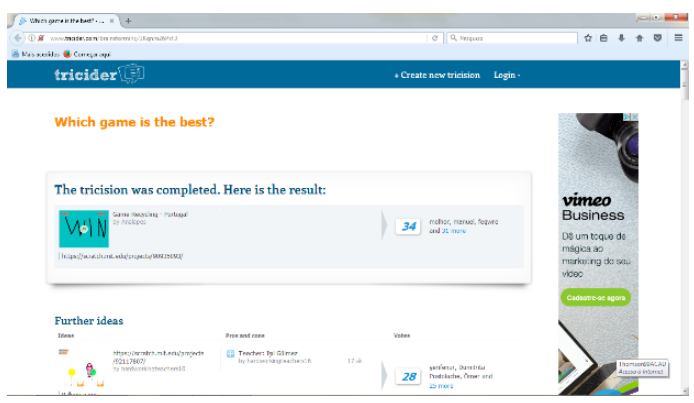

Figure 5. Win game

Scratch Game Project Links

Our Game Links:

\section{- Shopping for life}

Goal of the game -Teach the player to select the healthiest products for him and the environment.

Level 1 - Travel home, Level 2 - The meal choice

Level 3 - Shoppong cereals, Level 4 - Shopping

available at: (https://scratch.mit.edu/projects/91440262/)

\section{- Game House Hygiene Rules}

Learning to keep the world and your homes without pollution. Character: cat scratch Garden

Scenarios: House, Kitchen, Bedroom, Laundry, Garage,

Rules: the mouse try to fix it. The level ends when the scenario is completely clean available at

https://scratch.mit.edu/projects/90430243/)

\section{- $\quad$ Recycling}

The family is really concerned about recycling things in recycling bins will try somehow to recycle: plastic, glass, paper and batteries. If they fail, they lose 20 points but if they hit, theu will win 20 points.

Characteres: Father, Mother, Son and Daughter

Scenarios: House, Living room, Kitchen, Garage and a similar available at:

https://scratch.mit.edu/projects/90935093/

\section{- How to separate waste? Recycling}

The player wins a point when he /she touch the object that he/she puts in the right recycling bin but if the player puts the object in the wrong recycling bin, he/she loses one point. There are five scenarios,.

Scenery 1 - Beach,

Scenery 2 -Street,

Scenery 3 - Gardens,

Scenery 4 - School,

Scenery 5 - Coffee shops,

\section{- Food healthy labyrinth}

Learning to eat healthy food. This game has three levels.

With this project Portugal have owner The Nacional Quality Level, and European Quality Level.

ETwinning Quality Labels are granted to teachers with excellent eTwinning projects. They indicate that the project has obtained a certain National and European standard. For this reason, there are two labels: the National Quality Label and the European Quality Label.

National Quality Label 
What are the benefits?

The Quality Label is concrete a recognition to the teachers and the schools of high level of their eTwinning activities. To the students, this recognizes their work efforts and for the school in general, a public affirmation of their commitment to the quality and opening to the European collaborative work.

In full, a project has to achieve excellence in the following areas: (1) Pedagogical Innovation and Creativity, (2) Curricular Integration, (3) Collaboration between partner schools, (4) Creative use of ICT, (5) Sustainability and Transferability, and (6) Results and Benefits.

\section{European Quality Label}

The European Quality Label is a second mark of success and it is awarded automatically by the Central Support Service to schools in a project where at least two partners have already received the National Quality Label. As of October 2009, the European Quality Label is awarded only once a year and featured through the eTwinning Portal.

\section{B. Results, impact and documentation}

We did a collaborative international project that brings partners from different countries together and they create games using Scratch. Students communicated with people in Europe and created collaborative games. They learned about other cultures, used new tools and learned how other students learn in other countries. Students were divided into groups up to four. They made researches about games and worked individually and with groups with the guidance of teachers. Groups collaborated and competed to do the best works. Students learned from each other. They liked this type of informal learning. Their created their own games collaboratively. When they finished they shared them using online platforms where they could see each other's works and commented them. Commenting other students' works and collaborating with foreign students, this motivated our students. They were also motivated when they could achieve tasks and were ready to do the next task. At the end of project we organized a competition to choose the best work and we chose the best game using an online voting tool. During our project we participated in the International Codeweek event with the works we have been doing. Thus students had opportunities to share their works with the world. They got certificates of participation. By being in a competition and getting certificates, of course our students were highly motivated. This project improved student's motivation and success in computer science lessons. The Project helped teachers to develop students' ability in collaborative works, digital and social skills and awareness of cultural difference. My students learned that they can achieve much more through projects. This work encouraged other students in school. They wanted to participate in future projects. We had a lot of games that were created by students. We assessed 14 teachers from 11 different countries, 167 students. We created connections that in Future will last. We did a survey at the end of the project and partners were very happy about the project We used a lot of web 2.0 tools actively during the project.

\section{CONCLUSION}

Students have improved their learning process, a higher level of concentration and the collaborative learning due to the success of the pedagogical model created to support this international project.

Students communicated with each other from different European countries to develop collaborative games. They have learned about other cultures, new tools and how did they learned about each partner country. Teams were motivated to collaborate and compete to get the best results. Students learned from each other and they were very pleased with this type of informal learning.

This project helped teachers to developed student's ability of collaborative work, digital and social skills and awareness of cultural difference. With regards to the Portuguese students, they have realized that they can achieve better results through this kind of projects. This work has also encouraged other students in the school. We currently have a large number of students that want to participate in the next international projects.

In the future we will have more students in other similar project to continue this action-research study.

\section{REFERENCES}

[1] W. R. Borg, \&, M. D. Gall ,1989. Educational research: An introduction (5. ${ }^{\text {a }}$ Ed).London: Longman.

[2] C. P. Coutinho, 2006. Aspectos metodológicos da investigação em tecnologia educativa em Portugal,1985 a 2000. Braga: Universidade do Minho. pp. 1-12. Recuperado de http:// repositorium.sdum.uminho.pt/bitstream/1822/6497/1/Clara\%20 Coutinho\%20AFIRSE\%202006.pdf em 12 de Fevereiro de 2010

[3] Etwinning ttps:/ /www.etwinning.net/pt/pub/index.htm

[4] P21 Patnership For 21st Century Learning www.P21.org

[5] M. Fortin, 1999. O processo de investigação, da concepção à realização (3. ${ }^{\mathrm{a}}$ Ed.). Loures: Lusociência

[6] Partnership for 21st Century Skills ,2003. Learning for the 21st Century. http://www.p21.org/storage/documents/P21_Report.pdf

[7] Y. Kafai and M. Resnick EDS, 1996. Constructionism in Pratice: Designing, Thinking, and LEARNING IN A Digital World. Lawrence Erlbaum Associates, Inc., Mahwah, NJ

[8] A. Kay, 2010. Squeak etoys, children, and learning. http://www.squeakland.org/resources/articles (12/3)

[9] S. Papert, 1980. Mindstorms: Children, Computers, and Powerful Ideas. BasicBooks, New York

[10] M. Resnick, 2002. Rethinking Learning in the Digital Age. In The Global Information Technology Report:Readiness for the Networked World, edited by G. Kirkman. Oxford University Press.http://llk.media.mit.edu/papers/mres-wef.pdf

[11] M. Resnick, 2007. Sowing the Seeds for a More Creative Society. Learning and Leading with Technology.

[12] M. Resnick , J. Maloney, , A., Monroy-Hernández, N. Rusk, E. Eastmond, K. Brennan, A.Millner, E. Rosenbaum, J. Silver, B. Silverman, and Y. Kafai, 2009. Scratch: Programming for all. Comm. ACM 52, 11, 60-67

[13] M. Resnick,. N. Rusk, Y. Kafai, J. Maloney, et al. 2003. A Networked, Media -Rich Programming Environment to Enhance Technological Fluency at After-School Centers in Economically-Disadvantaged Communities. Proposal to the National Science Foundation, project funded 2003 - 2007

[14] J. Sternmetz, 2002. Computers and squeak as environments for learning. In M. Guzdial and K. Rose, Eds., Squeak: Open Personal Computing and Multimedia, Prentice-Hall, Inc., Upper Saddle River, NJ. 453-482. 